\title{
ALDEHYDE FORMATION IN FROZEN MACKEREL (SCOMBER SCOMBRUS) IN THE PRESENCE AND ABSENCE OF INSTANT GREEN TEA
}

\author{
Rabia Alghazeer, Suhur Saeed and Nazlin K.Howell \\ School of Biomedical and Molecular Sciences, University of Surrey, Guildford, \\ Surrey, United Kingdom GU2 7XH
}

\begin{abstract}
The effect of frozen storage on lipid peroxidation in Atlantic mackerel (Scomber scombrus) stored for up to 26 weeks at -10 or $-80^{\circ} \mathrm{C}$ (control), with and without green tea antioxidants, was investigated. Hydroperoxides (PV) and aldehydes (TBARS) were measured by HPLC and LC-MS and hexanal by GC. There was an increase in peroxide value which was associated with an increase in aldehydes followed by hexanal increase with storage time and at a higher temperature of $-10^{\circ} \mathrm{C}$ compared with samples stored at $-80^{\circ} \mathrm{C}$. Although TBARS is a common assay used to follow malondialdehyde formation, other aldehyde products can also react with thiobarbituric acid to give the red chromogen. Analysis of aldehyde-TBA adducts by LC-MS confirmed the presence of malondialdehyde and in particular, we report the production of gluteraldehyde for the first time in stored frozen fish. Green tea (at 250 ppm) substantially slowed down the oxidation process whereas at 500 ppm was less effective.
\end{abstract}

Keywords: Frozen fish, lipid peroxidation, malondialdehyde, gluteraldehyde, hexanal, green tea

Running title: Aldehyde formation in frozen mackerel (Scomber scombrus) in the presence and absence of instant green tea

Correspondence to: Nazlin K Howell, School of Biomedical and Molecular Sciences, University of Surrey, Guildford, Surrey GU2 7XH, UK.

Tel: 441483686448 E-mail: N.Howell@surrey.ac.uk 


\section{Introduction}

Atlantic mackerel contains 2-4 \% lipids which comprise high levels of polyunsaturated acids that are prone to oxidation, resulting in off-flavours, changes in colour and texture and loss of nutrients (Ackman 1989; Ericson \& Hung 1997; Harris \& Tall 1994; Kolakowska 2002; Saeed \& Howell 2002b). Primary lipid peroxidation products include hydroperoxides that are unstable and decompose to generate various secondary products such as aldehydes that can contribute to food rancidity. Aldehydes are cytotoxic compounds due to their reactivity towards nucleophiles and sulphydryl groups of protein and nucleophilic acids or related amino acids. Consequently, in the body, they induce cell injury and death and result in several diseases such as atherosclerosis and cancer (Esterbauer, 1982; Hoberman \& San George, 1988). In addition, cytotoxicity increases with increasing chain length of the aldehydes (Esterbauer, Zollner, \& Schaur 1990). Unlike free radicals, aldehydes can easily diffuse from the production site and spread the damage further (Esterbauer 1982; Esterbauer at.al., 1990).

Aldehydes can cross-link with different compounds in muscle such as proteins, and consequently increase muscle hardness and toughness. The reaction of aldehydes, particularly those with di-functional aldehydic groups such as gluteraldehyde (GLA) and malondialdehyde (MDA), with amino groups in proteins or DNA can result in structural damage and change in their functionality (Addis 1986; Gerrard and Brown 2002; Nair, Cooper, Vietti, \& Turner 1986). In addition, cross-linking with proteins can result in aggregation and protein insolubility. According to sensory assessment, an increase in hexanal levels correlates with the enhancement of rancid odour and offflavours. Secondary and final oxidation products are a reliable indicator of flavour deterioration in fish products (Shahidi 1998). Therefore, lipid oxidation products namely MDA, GLA and hexanal were investigated to follow the development of oxidative rancidity in Atlantic mackerel.

In this study, instant green tea was tested as a natural antioxidant to prevent or retard the development of oxidative rancidity in fish, since it has been reported that synthetic antioxidants may cause toxicity (Barlow 1990;Kaur \& Kappor 2001; Prior \& Cao 2000). Tea catechins possess strong scavenging capacity for free radicals and are reported to have significantly higher scavenging activities compared with vitamin $\mathrm{E}$ 
and ascorbic acid; they also possess metal-chelating capacity (Jo, Son, Son, \& Byun 2003;Nanjo, Goto, Seto, Suzukim, Sakal, \& Hara 1996; Tang, Kerry, Sheehan, \& Buckley 2002; Unno, Sugimoto, \& Kakuda 2000). However, the role of whole instant tea as antioxidant in fatty fish has not been assessed. Many methods have been used to follow the extent of lipid oxidation including peroxide value (PV) and thiobarbituric acid reactive substances (TBARS), gas chromatography (GC) and liquid chromatography-mass spectrometry (LC-MS). TBA can react with aldehydes to produce specific pigments. In the present study, the TBARS method by LC-MS was used not only to identify MDA but also GLA. TBA can react with products of lipid peroxidation such as hydroperoxides and conjugated aldehydes to produce substances that absorb at $535 \mathrm{~nm}$, similar to the product of MDA with TBA whereas, GC was used to determine hexanal (Dahle, Hill, \& Holman 1962; Draper \& Hadley 1990; Kakuda, Stanley, \& van de Voort 1981).

\section{Materials and methods}

\subsection{Materials}

Atlantic mackerel (Scomber scombrus) was supplied by M \& J Seafood, Farnham, UK. Instant green tea was provided by Tokyo Nikken Foods Co. Ltd. Japan. 3,3,3Tetraethoxy propane (TEP), thiobarbituric acid (TBA) and glutaraldehyde standard, sodium thiosulphate, starch, potassium iodide, glacial acetic acid and chloroform were purchased from Sigma-Aldrich Company Ltd, Poole, England. All reagents used were analytical grade.

\subsection{Methods}

\subsubsection{Sample preparation}

Eighty matched deboned fillets (about $6 \mathrm{~kg}$ ) of Atlantic mackerel were used. In order to facilitate mixing of green tea, the fillets were minced and divided into groups. One group was stored at $-80{ }^{\circ} \mathrm{C}$, a second group was frozen at $-10^{\circ} \mathrm{C}$ without antioxidant as a control, and the third and fourth groups were mixed with 250 or 500 ppm green tea respectively and stored at $-10{ }^{\circ} \mathrm{C}$. Tests were conducted at time zero, 
and subsequently at $4,8,16$ and 26 weeks of storage to investigate lipid oxidation during frozen storage.

\subsubsection{Lipid extraction from Atlantic mackerel}

Lipid was extracted from fresh minced mackerel by the Bligh and Dyer method as modified by Saeed and Howell (1999a). Minced fish was homogenised with methanol and chloroform (2:1) for $4 \mathrm{~min}$. The fish homogenate was centrifuged for $10 \mathrm{~min}$ at $3000 \mathrm{x} \mathrm{g}$. The lower chloroform phase containing the lipid was filtered and chloroform was evaporated. The oil extracted was stored under nitrogen at $-80^{\circ} \mathrm{C}$ for further analysis.

\subsubsection{Peroxide value}

Air was expelled from a conical flask by using nitrogen gas. Fish oil (0.5 g) was weighed into the flask followed by adding $10 \mathrm{ml}$ chloroform and $15 \mathrm{ml}$ acetic acid. After that, $1 \mathrm{ml}$ fresh saturated potassium iodide was added. The flask was sealed and swirled gently to mix the solution for $1 \mathrm{~min}$ and then placed in a dark cupboard for 1 min. Subsequently about $1 \mathrm{ml}$ starch solution was added. The coloured solution was titrated with $0.002 \mathrm{~N}$ sodium thiosulfate solution. A control sample without the fish oil was also analysed. Peroxide value was calculated as follows:

$\mathrm{PV}=\frac{(\mathrm{PV} \text { titre }-\mathrm{PV} \text { blank }) \times \mathrm{N} \times 1000}{\text { Weight of fat used }}$

Where PV titre $=\mathrm{ml}$ of sodium thiosulphate solution used in sample

PV blank $=\mathrm{ml}$ of sodium thiosulphate used in blank

$\mathrm{N}=$ concentration of thiosulphate solution

\subsubsection{Thiobarbituric acid reactive substances (TBARS)}

Thiobarbituric acid (TBA) reacts with TBA-reactive substances (TBARS) such as MDA under acidic conditions to form a chromagen which can be measured by HPLC (Young and Trimble 1991) and LC-MS at $532 \mathrm{~nm}$.

\subsubsection{Sample preparation}


Fish muscle $(1 \mathrm{~g})$ was homogenised with $2.5 \mathrm{ml}$ distilled water followed by the addition of $100 \mu \mathrm{BHA}$ to prevent further oxidation and $500 \mu \mathrm{L}$ of $25 \% \mathrm{HCl}$ and 500 $\mu 11 \%$ TBA. The mixture was vortexed for $20 \mathrm{sec}$ and incubated in a water bath at 90 ${ }^{\circ} \mathrm{C}$ for $1 \mathrm{~h}$ and cooled down to $20{ }^{\circ} \mathrm{C}$. Methanol (HPLC grade) $(1 \mathrm{ml})$ and $400 \mu \mathrm{l}$ of $\mathrm{NaOH}(1 \mathrm{M})$ were added to $400 \mu \mathrm{l}$ of sample. The mixture was centrifuged at 13,000 $\mathrm{x} g$ for $10 \mathrm{~min}$, and transferred to a vial for analysis. An aliquot $(50 \mu \mathrm{l})$ was injected into the HPLC (Spectra system AS 3000) for analysis. The red complex separation was achieved on a $150 \times 3 \mathrm{~mm}$ column containing Luna $5 \mu \mathrm{m}$ phenylhexyl C18 packing (Phenomenex, Macclesfield, UK) and the sample was eluted with phosphate buffer ( $\mathrm{pH}$ 6.5) solution. The flow rate was $1 \mathrm{ml} / \mathrm{min}$. The peak assignment and quantification was performed by using standards which were prepared from 1,1,3,3 tetraethoxypropane.

\subsubsection{Liquid Chromatography-Mass Spectrometry (LC-MS)}

LC-MS equipment (ThermoFinnigan, San Jose, CA) consisted of a Surveyor MS pump, an autosampler with a $20 \mu \mathrm{lloop}$, and a PDA/ UV detector. The UV detector was set to record at 530, 280 and $450 \mathrm{~nm}$. Mass spectra were recorded in the negative ion mode for MDA and positive ion for GLA in the range m/z 240 to $\mathrm{m} / \mathrm{z} 600$. Zoom scan mode operation by an interfaced LCQ Deca XP plus mass spectrometer fitted with an ESI source (ThermoFinnigan) was used to measure the collision induced MS/MS spectrum of the adduct form. The software for the control of the equipment and acquisition and treatment of data was Xcalibar version 1.3. Compound separation was achieved on a $150 \times 3 \mathrm{~mm}$ column containing Luna $5 \mu \mathrm{m}$ phenylhexyl packing (Phenonemex, Macclesfield, UK.). The chromatographic conditions were: flow rate $0.3 \mathrm{ml} / \mathrm{min}$, sample injection volume $50 \mu \mathrm{l}$ and mobile phases A) $2 \%$ acetonitrile, 0.5 $\%$ acetic acid, pH 2.68 and B) $99.5 \%$ acetonitrile, $0.5 \%$ acetic acid. A line gradient was used and the run time was $35 \mathrm{~min}$. The spray needle was set to $3.5 \mathrm{kV}$ in the negative ion mode. The inlet capillary temperature was maintained at $350{ }^{\circ} \mathrm{C}$, gas flow rate 80 arbitrary units and auxiliary gas flow, 10 (arbitrary units). Mass detection was performed in the negative mode, for $\mathrm{m} / \mathrm{z}$ between 200-500. In order to detect the TBA: GLA product, more sensitive target $\mathrm{MS}^{\mathrm{n}}$ experiments were used to seek compounds with a particular molecular ion that might otherwise have been overlooked e.g m/z 353 (for TBA: GLA). 


\subsubsection{Hexanal determination}

The hexanal method was kindly supplied by Masterfood plc (Masterfoods, Central Nutrition and Microbiological Laboratories, UK).

\subsubsection{Standards preparation}

Stock hexanal $(0.1 \mathrm{~g})$ was weighed into a $100 \mathrm{ml}$ volumetric flask with cyclohexane. Stock isobutyl acetate $(0.1 \mathrm{~g})$ was weighed into $100 \mathrm{ml}$ volumetric flask with cyclohexane. Internal standard: $2 \mathrm{ml}$ of stock isobutyl acetate (IBA) was pipetted into $100 \mathrm{ml}$ volumetric flask and was made up to $100 \mathrm{ml}$ with cyclohexane. Working standard: $2 \mathrm{ml}$ of both stock solutions hexanal and isobutyl acetate were pipetted into a $100 \mathrm{ml}$ volumetric flask and made up volume by adding cyclohexane.

\subsubsection{Sample preparation}

The sample (10 g) in triplicate was weighed and saturated sodium chloride solution $(150 \mathrm{ml})$ and an internal standard, isobutyl acetate $(2 \mathrm{ml})$ were added. The mixture was refluxed on a heating mantle for $15 \mathrm{~min}$ and left to cool for $15 \mathrm{~min}$. The cyclohexane layer was injected into the gas chromatograph. The chromatographic conditions were: the run time was $17.60 \mathrm{~min}$ and injection volume $4 \mu \mathrm{l}$. The retention time for isobutyl acetate was approximately $6.2 \mathrm{~min}$ and for hexanal 7 minutes. The concentration of hexanal was calculated as follows:

$\frac{\text { sample ratio }}{\text { average standard }} \times$ hexanal standard concentration $\times \frac{\text { internal standard amount }}{\text { weight of sample }}$

Average standard ratio $=$ average ratio of calibration working standard run . Internal standard amount $=2 \mathrm{ml}$.

\section{Statistical analysis}

The results are expressed as mean \pm SD. Significant differences values were assessed with the unpaired Student's t-test. The significance level chosen for the statistical analysis was $\mathrm{p}<0.05$. 


\section{Results and discussion}

In the present work the influence of time (up to 26 weeks) and temperature $\left(-10{ }^{\circ} \mathrm{C}\right.$ and $-80^{\circ} \mathrm{C}$ ) on lipid deterioration in the presence and absence of green tea antioxidant (250 and $500 \mathrm{ppm}$ ) produced during the frozen storage of fatty fish, in particular mackerel fish, was significant. The results of all experiments indicated an increase in lipid oxidation products with storage time; the highest value was observed in the sample stored at $-10{ }^{\circ} \mathrm{C}$ without green tea.

\subsection{Peroxide Value (PV)}

The PV value rose sharply until 16 weeks and then fell dramatically in all samples (Fig. 1). A faster increase in PV values was obtained at $-10^{\circ} \mathrm{C}$ without green tea in contrast to a slow increase at $-80^{\circ} \mathrm{C}$ (Fig. 1) confirming previous results (Saeed \& Howell 2002a). PV values were significantly higher in samples stored at $-10{ }^{\circ} \mathrm{C}$ without green tea compared with antioxidant treated samples particularly at $250 \mathrm{ppm}$ green tea concentration $(\mathrm{p}<0.05)$ (Fig. 1). In contrast, samples mixed with $500 \mathrm{ppm}$ green tea at $-10{ }^{\circ} \mathrm{C}$ had higher PV values than the samples treated with $250 \mathrm{ppm}$ which indicated that a low tea concentration is more effective in controlling oxidation.; it has been reported that a higher concentration of green tea may act as a pro-oxidant (Honglian \& Etsuo 2001). A decrease in the level of primary oxidation products is related to hydroperoxide degradation, producing secondary lipid peroxidation products (Undeland 2001).

\subsection{Hexanal content}

Figure 2 shows a GC chromatogram of hexanal extracted from fish muscle stored at $-10^{\circ} \mathrm{C}$ for 8 weeks. Hexanal levels rose significantly after 16 weeks in samples stored at $-10{ }^{\circ} \mathrm{C}$ without antioxidant compared with samples stored at $-10{ }^{\circ} \mathrm{C}$ with $250 \mathrm{ppm}$ green tea $(\mathrm{p}<0.01)$ (Fig. 3). There was a major increase $(p<0.001)$ in samples stored at $-10^{\circ} \mathrm{C}$ compared with those stored at $-80^{\circ} \mathrm{C}$. These results confirmed the trend for PV and TBARS results and the increasing concentration on storage showed that hexanal is one of the final products of lipid peroxidation (Sanches-Silva, Rodr'ýguezBernaldo de Quir'os, L'opez-Hern'andez, \& Paseiro-Losada 2004). 


\subsection{Thiobarbutric acid reactive substances (TBARS)}

Figure 4 shows a typical TBARS HPLC chromatogram obtained from fish muscle. Overall, there was an increase in the level of TBARS during frozen storage, particularly in samples stored at $-10^{\circ} \mathrm{C}$ compared with $-80{ }^{\circ} \mathrm{C}(\mathrm{p}<0.01)$ or $-10{ }^{\circ} \mathrm{C}$ in the presence of green tea $(250 \mathrm{ppm})(\mathrm{p}<0.05)$ (Fig. 5). After 10 weeks, there was a decrease probably due to thiobarbituric acid (TBA)-reactive substances cross linking with proteins (Saeed, Fawthrop, \& Howell 1999) (Fig. 5). As mackerel is a fatty fish the values obtained over the whole storage period were relatively high, similar to previous studies (Aubourg, Sotelo, \& Perez-martin 1982; Kurade \& Baranowski 1987; Saeed et.al., 2002b).

\subsubsection{LC-MS of aldehyde TBA-adducts}

TBARS is a common assay used to follow lipid oxidation in foodstuffs (Ladikos and Lougovois 1999) based on spectrophotometric determination of malondialdehyde. However, other aldehyde products can react with thiobarbutric acid and thus the TBARS method can also be used to assess other aldehydes formed during lipid oxidation (Vyncke 1975). The red chromogen was analysed by LC-MS in full scan mode for the identification of aldehyde-TBA adducts. Aldehydes-TBA adducts were identified by comparing the retention time (tr) with the standard and confirmed by LC-MS. A full scan chromatogram at $200-500 \mathrm{~m} / \mathrm{z}$ for the parent condensation adduct for MDA-TBA is shown in Fig. 6. Absorbance maxima for the parent MDA: TBA 1:2 complex was measured at 525 to $530 \mathrm{~nm}$; the results agreed with previous studies (Guillen-Sans and Guzman-Chozas 1998; Janero 1990; Jardine, Antolovich, Prenzler, \& Robards 2002). Identification was based on the negative parent ion at $\mathrm{m} / \mathrm{z}$ 323 (MS) (Fig. 7a) and subsequent fragmentation pattern consisting of a loss of $\sim 102$ $\mathrm{mu}$ from the parent ion to leave a base peak fragment $\mathrm{m} / \mathrm{z} \sim 121$ in $\mathrm{MS}^{2}$ (Fig. 7b) and a loss of $\sim 144$ mu that gave a base peak fragment $\sim 179$ in $\mathrm{MS}^{3}$ (Fig. 7c). Possible fragmentation products are shown in Fig. 8.

The chemical structure of GLA with TBA is illustrated in Fig. 9 and its possible fragmentations in Fig. 10. Analysis by MS showed that the parent ion $[M-H]^{+}$was within $+1 \mathrm{mu}$ of the theoretical value for the fish sample and the standard. The GLA: 
TBA complex fragmented to give product ions of $\mathrm{m} / \mathrm{z} \sim 335\left(\mathrm{MS}^{2}\right)$ (Fig. 11A) and $\sim 194\left(\mathrm{MS}^{3}\right)$ (Fig. 11B).

In this study we have shown the formation of glutaraldehyde in frozen fish for the first time and confirmed its presence and that of malondialdehyde by LC-MS. Recently, the presence of aldehydes in foods including meat has attracted attention because of their effect on food quality and safety. Aldehydes including saturated aldehydes such as hexanal, formaldehyde and propanal extracted from the headspace by GC analysis of fish tissue have been reported (da Cunha Veloso, da Silva, Santos, $\&$ Andrade 2001). In addition, an unsaturated aldehyde like malonaldehyde (Saeed et.al., 2002b) extracted from fish muscle is a well known lipid peroxidation product, while other unsaturated aldehydes, which can be formed from the break down of hydroperoxides, like gluteraldehyde, need more investigation. Since fatty fish like mackerel has a high content of polyunsaturated fatty acids, lipid peroxidation products particularly aldehydes contribute to rancidity and food deterioration (Tsaknis, Lalas, \& Evmorfopoulos 1999), including protein aggregation and toughening of fish during frozen storage (Saeed et.al., 2002b) and DNA damage. Protein-aldehyde crosslinking results from the interaction of aldehydes with $\varepsilon$-amino group in lysine, sulfhydryl group of cysteine and the imidazole group of histidine (Hoberman et.al., 1988) leading to changes in the primary structure of proteins that induce changes in the secondary and tertiary structures (Meng, Chan, Rousseau, \& Li-Chan 2005). Changes in protein structure result in changes in protein functionality and may ultimately cause extensive cell damage and death (Chen, Yang, Jiao, \& Zhao 2002).

In this study, instant whole green tea at low concentration (250 ppm) was an effective antioxidant, this result supports previous findings that natural phenolic compounds are effective in preventing rancidity of many lipid systems, in particular fish oils (Medina, Satue-Gracia, German, \& Frankel 1999; Ramanathan 1992) and minced muscle (Fagbenro and Jauncey 1994; Ikawa 1998), as well as acting as an anticarcinogenic substances. The biological and chemical properties of tea are related to the polyphenols content called catechins including $(+)$-catechin $(\mathrm{C}),(-)$-epicatechin (EC), (-)- gallocatechin (GC), (-)-epicatechin gallate (EGC), (-)- epigallocatechin gallate (ECG), (-)-epigallocatechin gallate (EGCG) (Ninomiya, Unten, \& Kim 1997) (Fig. 12); the structure comprises $\mathrm{OH}$ groups which scavenge free radicals generated during lipid peroxidation and chelate metal ions. Compared with alpha tocopherol, catechins are reported to have a substantial antioxidants effect when they are mixed 
with cooked meat and fish products (Tang, Kerry, Sheehan, Buckley, \& Morrissey 2001a; Tang, Kerry, Sheehan, Buckley, \& Morrisely 2001b; Tang, Kerry, Sheehan, \& Buckley 2002) due to protection or regeneration of alpha tocopherol which already exists in the meat or in the fish muscles. Moreover green tea extracts were found to be good antioxidants, more effective than rosemary, in canola oil, pork lard and chicken fat heated to $100{ }^{\circ} \mathrm{C}$ (Chen, Wangl, Chan, Zhang, Chung, \& Liang 1998) and had a higher antioxidant activity than that of vitamin $\mathrm{C}$ and $\mathrm{E}$. However, as our results show, a high level instant green tea of $500 \mathrm{ppm}$ was not as effective as 250 ppm for reducing peroxidation of unsaturated fatty acids.

In many instances, for example in our previous work (Sarkardei and Howell, 2007), we have found that very high levels of rosemary to act as a prooxidant due to production of excessive levels of antioxidant free radicals (Halliwell, 1993). In this study, it is possible that $250 \mathrm{ppm}$ green tea was sufficient to scavenge the free radicals until 16 weeks, whereas $500 \mathrm{ppm}$ is excessive After, 16 weeks storage, $500 \mathrm{ppm}$ produced lower lipid oxidation products particularly hexanal, which is the final product. After 26 weeks inhibition of lipid oxidation was minimal as all the antioxidants were probably used up.

In addition, it has been pointed out that a high concentration of tea induce apoptosis in many type of cells (Chen, Yang, Jiao, \& Zhao 2002; Razat and John 2005; Zho, He, Cheng, \& Xin 1989). The effect of antioxidants depends on many factors such as mixing ability, activity in different lipid systems, and stability at the time of processing (Giese 1996; Houlihan \& Ho 1985). We have shown that whole instant green tea used at the right concentration may delay or inhibit lipid oxidation and can be used as natural antioxidants in raw minced fatty fish tissue to enhance preservation. Further studies on ascertaining optimum levels of green tea including polyphenol fractions for food preservation and their effect on safety using cultured human cells is underway.

\section{Conclusion}

Lipid peroxidation products particularly aldehydes contribute to rancidity and food deterioration, toughening of fish during frozen storage as well as protein and DNA damage via crosslinking. In this study we have shown the formation of glutaraldehyde in frozen fish for the first time and confirmed its presence and that of 
malondialdehyde by LC-MS. Green tea used at the right concentration may delay or inhibit lipid oxidation and can be used as natural antioxidant in both food preservation and medical applications. However, studies on optimum levels of green tea require further investigation.

\section{References}

Ackman, R. G. (1989). Fatty acids. In Marine biogenic lipids, fats and oils. R. G. Ackman, ed. Pp. 103-137. Boca Raton, (FL) USA: CRC Press.

Addis, P. B. (1986). Occurrence of lipid oxidation products in foods. Food and Chemical Toxicology, 24, 1021-1030.

Aubourg, S., Sotelo, C., \& Perez-martin, R. (1982). Assessment of quality changes in frozen sardine (Sardina pilchardus) by fluorescence detection. Journal of the American Oil Chemists' Society, 75, 575-580.

Barlow, S. M. (1990). Toxicological aspects of antioxidants used as food additives. In Food antioxidants. B. J. Hudson, ed. Pp. 253-307. New York: Elsevier.

Chen, L., Yang, X., Jiao, H., \& Zhao, B. (2002). Tea catechins protect against leadinduced cytotoxicity, lipid peroxidation, and membrane fluidity in HepG2 cells. Toxicological science, 69, 149-156.

Chen, Z.Y., Wangl, Y., Chan, P.T., Zhang, Z., Chung, H.Y., \& Liang, C. (1998). Antioxidative activity of green tea catechin extract compared with that of rosemary extract. JAOCS, 75, 1141-1145.

da Cunha Veloso, M., da Silva, V., Santos, G., \& Andrade, J. (2001). Determination of aldehydes in fish by high-performance liquid chromatography. Journal of chromatographic science. 39, 173-176. 
Dahle, K. L., Hill, G. \& Holman, R. T. (1962). The thiobarbituric acid reaction and the autoxidations of polyunsaturated fatty acid methyl esters. Arch Biochim Biophys 98: $253-261$.

Draper, H., \& Hadley, M. (1990). Malondialdehyde determination as index of lipid peroxidation. In Methods in Enzymology. Pp. 421-431. Academic Press.

Ericson, M. C., \& Hung, Y. C. (1997). Quality in Frozen Food. New York: Chapman and Hall.

Esterbauer, H. (1982). Lipid peroxidation and cancer. In Free Radicals. Pp. 101-128. London: Academic Press.

Esterbauer, H., Zollner, H., \& Schaur, R. J. (1990). Aldehydes formed by lipid peroxidation: Mechanisms of formation, occurrence and determination. In Lipid Oxidation. C. Vigo, ed. Pp. 239-283. CRC Press, Boca Raton.

Fagbenro, O., \& Jauncey, K. (1994). Chemical and nutritional qualtity of fermented fish silage containing potato extracts. Food chemistry, 50, 383-388.

Gerrard, A. J., \& Brown, K. P. (2002). Protein cross-linking in food: mechanisms, consequences, applications and International. Congress series, 1245, 215.

Giese, J. (1996). Antioxidants: Tools for preventing lipid oxidation. Food technology, 11, 73-79.

Guillen-Sans, R., \& Guzman-Chozas, M. (1998). The thiobarbituric acid (TBA) reaction in foods: review. Critical review of food Science and Nutrition, 38, 315-330.

Harris, P., \& Tall, J. (1994). Substrate specificity of mackerel flesh lipoxygenase. Journal of food science, 59, 504-506.

Hoberman, H. D., \& San George, R. C. (1988). Reaction of tobacco smoke aldehydes with human hemoglobin. Journal of biochemical toxicology, 3, 105-119.

Halliwell, B., and Chirico, C. (1993). Lipid peroxidation: its mechanism, measurement and significance. American journal clinical nutrition, 57, 715S$725 \mathrm{~S}$. 
Honglian, N., \& Etsuo, N. (2001). Introducing natural antioxidants. In Antioxidants in food-practical applications. J. Pokorny, N. Yanishlieva, and M. Gordon, eds. Pp. 147-155. Cambridge, England: Woodhead Publishing Limited.

Houlihan, C. M., \& Ho., C. (1985). Natural antioxidants. In Flavor chemistry of fats and oils. D.B.Min and T.H.Smouse, eds. Pp. 117-143. AOCS, Champaign I linois.

Ikawa, K. (1998). Use of tea extracts (sanfood) in fish paste products. New Food Industries, 40, 33-39.

Janero, D. R. (1990). Malondialdehyde and thiobarbituric acid-reactivy as diagnostic indices of lipid peroxidation and peroxidative tissue injury. Free radical biology \& medicine, 9, 515-540.

Jardine, D., Antolovich, M., Prenzler, P. D., \& Robards, K. (2002). Liquid chromatography-mass spectrometry (LC-MS) investigation of the thiobarbituric acid reactive substances (TBARS) reaction. Journal of agricultural and food chemistry, 50, 1720-1724.

Jo, C., Son, J. H., Son, C. B., \& Byun, M. W. (2003). Functional properties of raw and cooked pork patties with added irradiated, freeze-dried green tea leaf extract powder during storage at $4^{\circ} \mathrm{C}$. Meat science, 64, 13-17.

Kakuda, Y., Stanley, D. W., \& van de Voort., F. R. (1981). Fluorometric analysis of 2-thiobarbituric acid reactive substances in turkey. Journal of the American Oil Chemists' Society, 58, 773.

Kaur, C., \& Kappor, H. C. (2001). Antioxidants in fruits and vegetables-the millennium's health. International Journal of Food and Science Technology, $36,703-725$.

Kolakowska, A. (2002). Lipid oxidation in food systems. In Chemical and functional properteis of food lipids. Z. Sikorski and A. Kolakowska, eds. Pp. 133-165. London, UK: CRC Press.

Kurade, S., \& Baranowski, J. (1987). Prediction of shelf-life of frozen minecd fish in terms of oxidative rancidity as measured by TBARS number. Journal of food science, 52, 300-302.

Ladikos, D., \& Lougovois, V. (1999). Lipid oxidation in muscle foods: a review. Food Chem, 35, 295-314. 
Medina, I., Satue-Gracia, M. T., German, J. B., \& Frankel, E. N. (1999). Comparison of natural polyphenol antioxidants from extra virgin olive oil with synthetic antioxidants in tuna lipids during thermal oxidation. Journal of agricultural and food chemistry, 47, 4873-4879.

Meng, G., Chan, J., Rousseau, D., \& Li-Chan, Y. (2005). Study of protein-lipid interactions at the bovine serum albumin/oil interface by Raman microspectroscopy . Journal of agricultural and food chemistry, 53, 845-852.

Nair, V., Cooper, C. S., Vietti, D. E., \& Turner, G. A. (1986). The chemistry of lipid peroxidation metabolites: cross-linking reactions of malondialdehyde. Lipids, 21,10 .

Nanjo, F., Goto, K., Seto, R., Suzukim, M., Sakal, M., \& Hara, Y. (1996). Scavenging effects of tea catechins and their derivatives on 1,1-diphenyl-2-picryl-hydrazyl radical. Free radical biology \& medicine, 21, 895-902.

Ninomiya, M., Unten, L., \& Kim, M. (1997). Chemical and physicochemical properteis of green tea polyphenols. In Chemistry and applications of green tea. T. Yamamoto, L. R. Juneja, D. C. Chu., \& K. Mujo, eds. Pp. 23-35. New York: CRC Press.

Prior, R. L., \& Cao, G. (2000). Flavonoids: Diet and health relationships. Nutrition in clinical care, 3, 297-288.

Ramanathan, L. (1992). Studies on the control of lipid oxidation in ground fish by some polyphenolic natural products. Journal of agricultural and food chemistry, 40, 17-21.

Razat, H., \& John, A. (2005). Green tea polyphenol epigallocatechin-3-gallate differentially modulates oxidative stress in PC12 cell compartments. Toxicology and Applied Pharmacology, 207, 212-220.

Saeed, S., Fawthrop, S. A. \& Howell, NK. (1999). Electron spin resonance (ESR) study on free radical transfer in fish lipid-protein interaction. Journal of the science of food and agriculture, 79, 1809-1816.

Saeed, S., \& Howell, N. K. (2002). Effect of lipid oxidation and frozen storage on muscle proteins of Atlantic Mackerel ( Scomber Scombrus). Journal of agricultural and food chemistry, 82, 579-586. 
Sarkardei, S., \& Howell, N. K. (2007). Effect of natural antioxidants on stored freezedried food product formulated using horse mackerel (Trachurus trachurus).

International Journal of Food Science and Technology. In press.

Sanches-Silva, A., A. Rodr'ýguez-Bernaldo de Quir'os, J. L'opez-Hern'andez, \& P. Paseiro-Losada. (2004). Determination of hexanal as indicator of the lipidic oxidation state in potato crisps using gas chromatography and highperformance liquid chromatography. Journal of chromatography. A, 1046, 7581.

Shahidi, F. (1998). Food Flavors: Formation, Analysis and Packaging Influences. Amsterdam: Elsevier.

Tang, S., Kerry, J.P., Sheehan, D., Buckley, D.J., \& Morrisely, P.A. (2001a). Antioxidative effect of added tea catechins on susceptibility of cooked red meat, poultry and fish patties to lipid oxidation. Food research international, 34, 651-657.

Tang, S., Kerry J.P., Sheehan D., Buckley D.J., \& Morrissey P.A. (2001b). Antioxidative effect of dietary tea catechins on lipid oxidation of long-term frozen stored chicken meat. Meat science, 57, 331-336.

Tang, S. Z., Kerry, J. P., Sheehan, D., \& D. J. Buckley. (2002). Antioxidative mechanisms of tea catechins in chicken meat systems. Food chemistry, 76, 4551 .

Tsaknis, J., Lalas, S., \& Evmorfopoulos, E. (1999). Determination of malondialdehyde in traditional fish products by HPLC. The Analyst, 124, 845.

Undeland, I. (2001). Lipid oxidation in fatty fish during processing and storage. In Farmed Fish Quality. S. C. Kestin and P. D. Warriss, eds. Pp. 261-275. Oxford: Fishing News Book.

Unno, T., Sugimoto, A., \& Kakuda, T. (2000). Scavenging effect of tea catechins and their epimers on superoxide anion radicals generated by a hypoxanthine and xanthine oxidase system. Journal of the science of food and agriculture, 80, 601-606.

Young, I. S., \& Trimble, E.R. (1991). Measurement of malondialdehyde in plasma by high performance liquid chromatography with fluorimetric detection. Annals of clinical biochemistry, 28, 504-508. 
Zho, B., He, X., Cheng, R., \& Xin, W. (1989). Scavenging effect of extracts of green tea and nature antioxidants on active radicals. Cell biophysics, 14, 175-185.

\section{Acknowledgements}

The authors would like to thank Prof. Mike Clifford and Hajo Roozendahl for assistance with the LC-MS. Funding for Rabia Alghazeer's studentship by the Government of Libya is gratefully acknowledged.

\section{List of Figures}

Fig. 1. Peroxide values obtained for mackerel stored: at $-80{ }^{\circ} \mathrm{C}$ and $-10^{\circ} \mathrm{C}$ in the presence or absence of green tea (250 or $500 \mathrm{ppm})$ for up to 26 weeks. Data represent the mean $\pm \mathrm{SD}$ of three experiments.

Fig. 2. Gas chromatography (GC) profile of hexanal extracted from mackerel fish stored at $-10^{\circ} \mathrm{C}$ for up to 4 weeks.

Fig. 3. Hexanal concentration in lipids extracted from mackerel stored at $-80{ }^{\circ} \mathrm{C}$ and $10{ }^{\circ} \mathrm{C}$ with 0,250 or $500 \mathrm{ppm}$ green tea for up to 26 weeks. Data represent the mean \pm SD of three experiments.

Fig. 4. HPLC Chromatogram of TBARS extracted from fresh fish.

Fig. 5. Thiobarbituric acid test values obtained for mackerel stored for up to 26 weeks at $-80{ }^{\circ} \mathrm{C}$ and at $-10{ }^{\circ} \mathrm{C}$ with 0,250 or $500 \mathrm{ppm}$ green tea. Data represent the mean \pm SD of three experiments.

Fig. 6. Chemical structure for MDA: TBA (1:2) adduct.

Fig. 7. Mass spectra of TBA: MDA obtained from lipid extracted from frozen mackerel stored at $-10^{\circ} \mathrm{C}$ for up to 8 weeks. LC-MS conditions as described in experimental section. A: MS-MS spectrum of m/z 323, B: $\mathrm{MS}^{2}$ spectrum of $221 \mathrm{~m} / \mathrm{z}$ and $\mathrm{C}: \mathrm{MS}^{3}$ spectrum of $178 \mathrm{~m} / \mathrm{z}$.

Fig. 8. Possible fragmentation of MDA: TBA adducts during $\mathrm{MS}^{\mathrm{n}}$.

Fig. 9. Chemical structure for TBA: GLA adduct.

Fig. 10. Possible fragments obtained from parent peak $(353 \mathrm{~m} / \mathrm{z})$ for GLA: TBA adducts formed during collision activated dissociation. 
Fig. 11. Mass spectra of TBA: GLA obtained from lipid extracted from frozen mackerel stored at $-10{ }^{\circ} \mathrm{C}$ for up to 16 weeks. A: $\mathrm{MS}^{2}$ spectrum of $335 \mathrm{~m} / \mathrm{z}, \mathrm{B}: \mathrm{MS}^{3}$ spectrum of $194 \mathrm{~m} / \mathrm{z}$.

Fig. 12. Chemical structures of tea cathechins. 
ALDEHYDE FORMATION IN FROZEN MACKEREL (SCOMBER SCOMBRUS) IN THE PRESENCE AND ABSENCE OF INSTANT GREEN TEA

\section{Rabia Alghazeer, Suhur Saeed and Nazlin K.Howell}

School of Biomedical and Molecular Sciences, University of Surrey, Guildford, Surrey, United Kingdom GU2 7XH

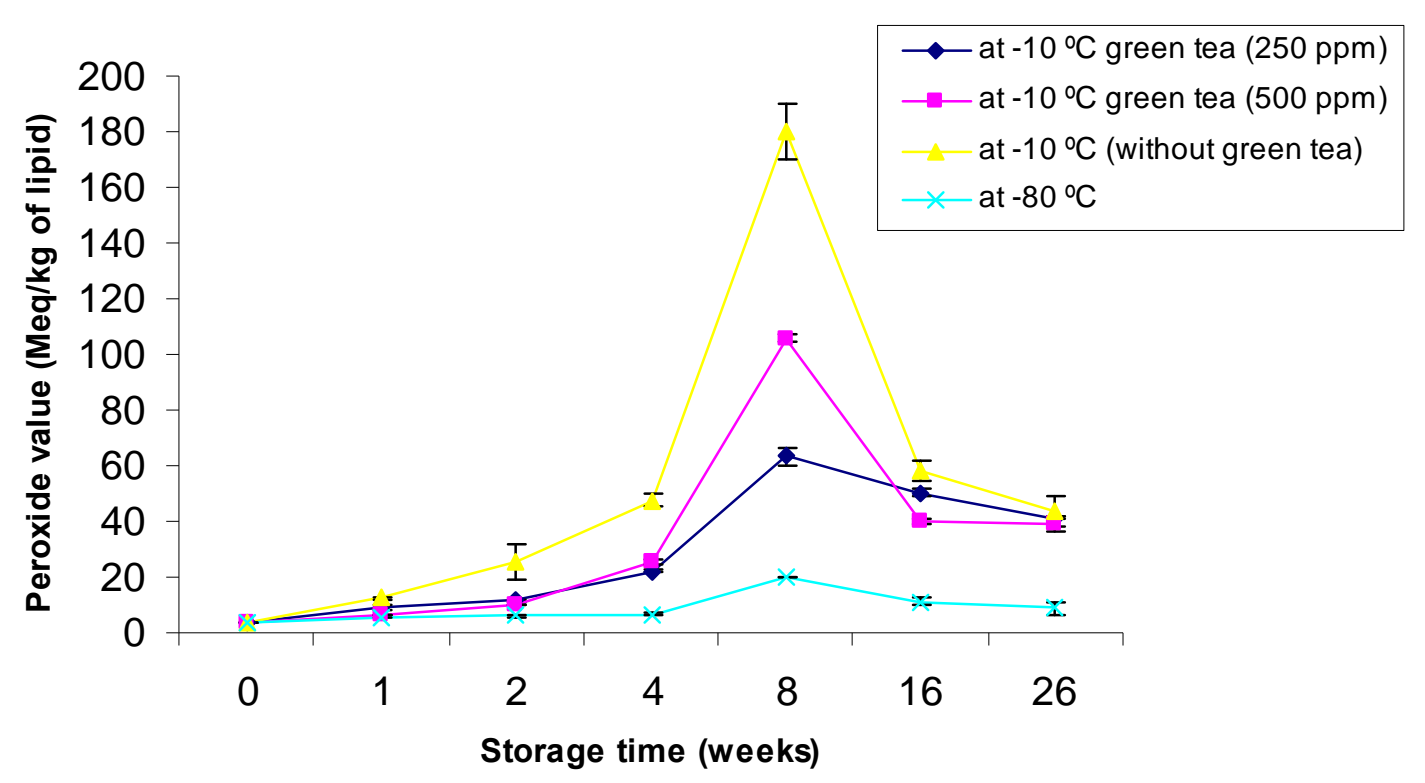

Fig. 1

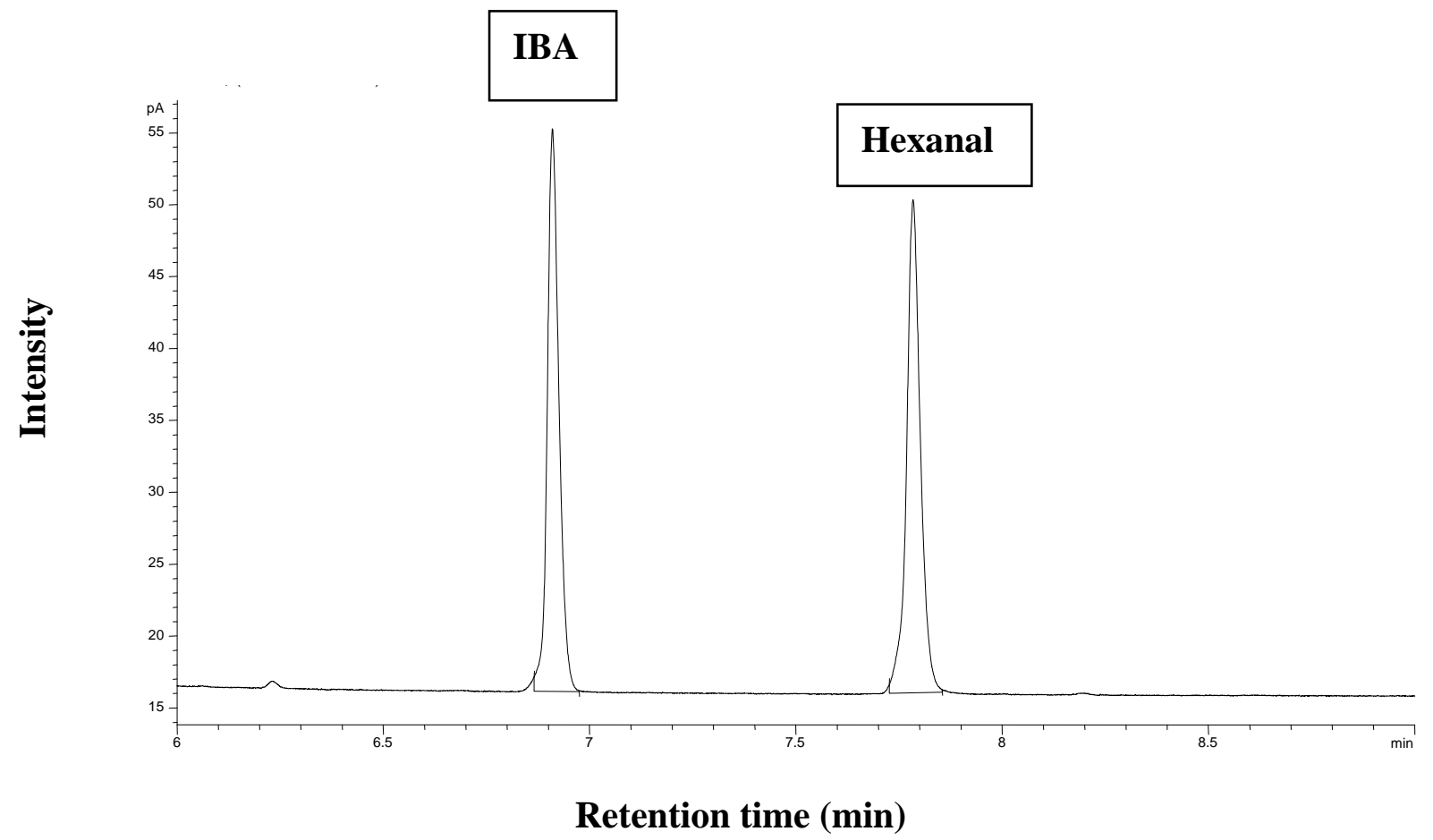

Fig. 2 


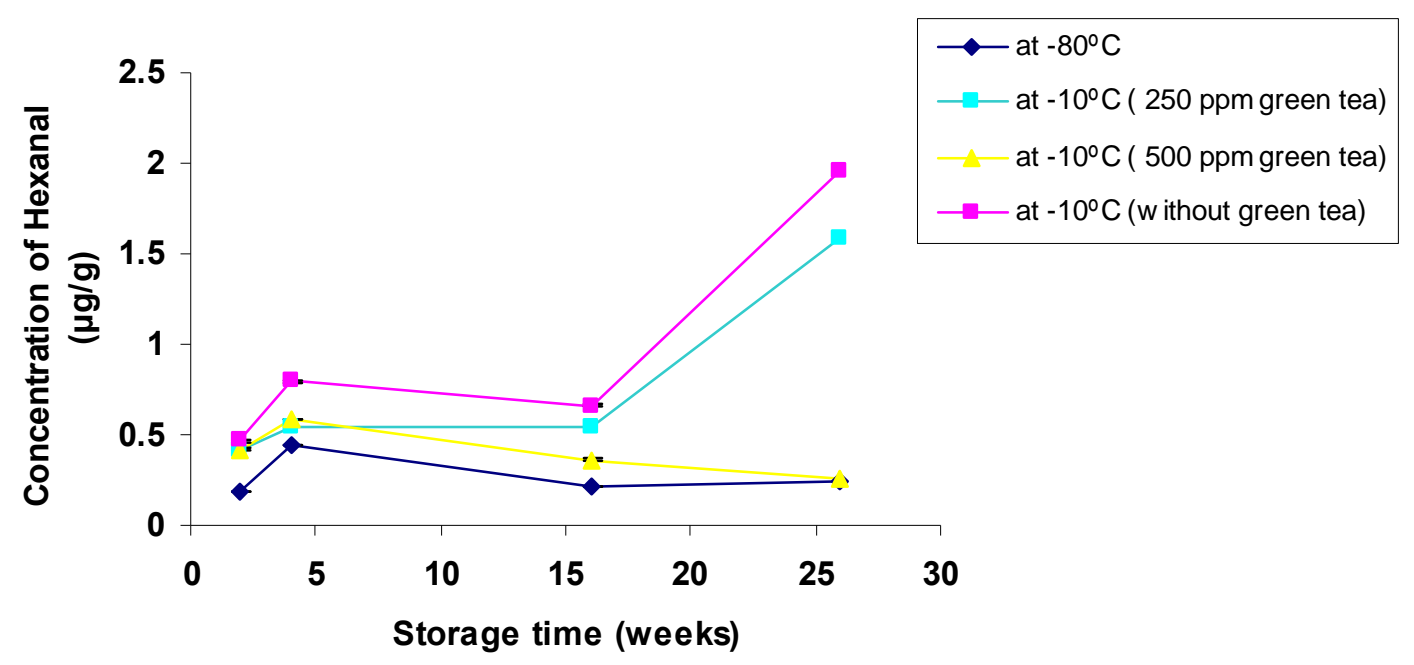

Fig. 3

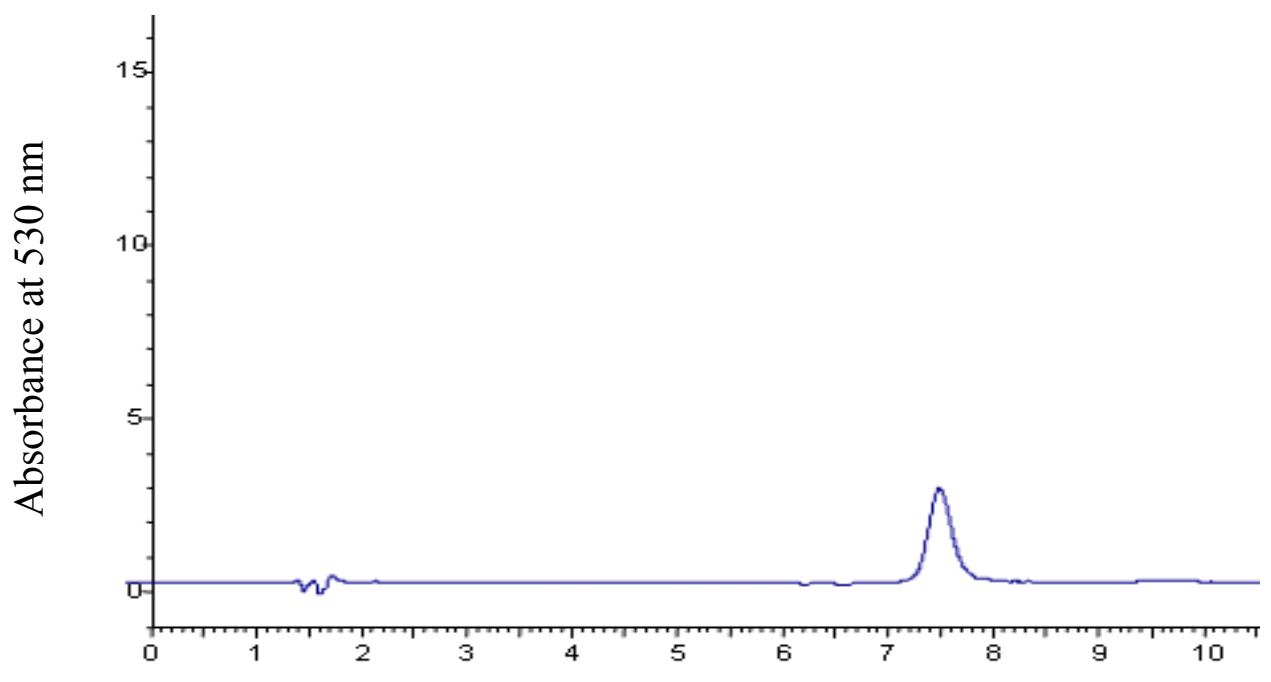

Time (min)

Fig. 4 


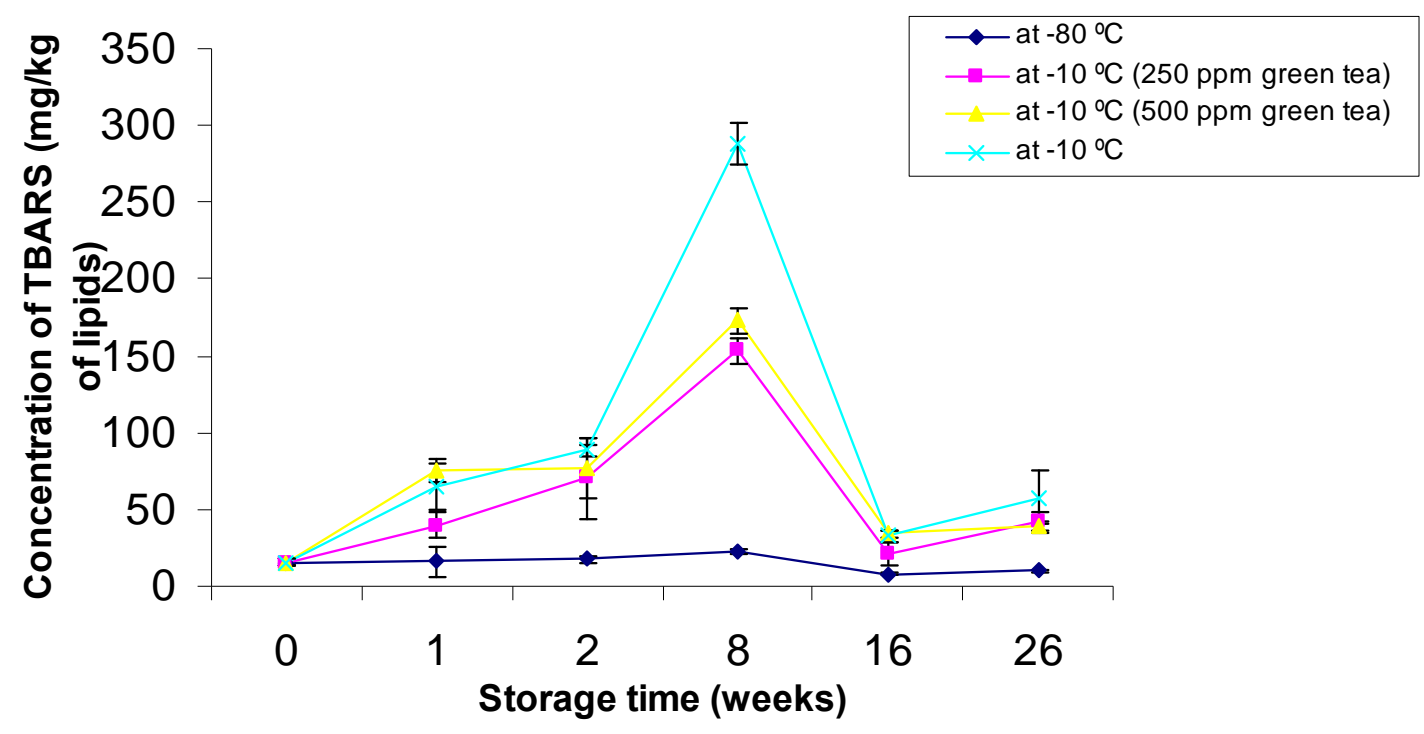

Fig. 5<smiles>O=C1NC(=S)NC(=O)C1=CC=Cc1c(O)nc(S)nc1O</smiles>

$\mathrm{C}_{11} \mathrm{H}_{8} \mathrm{~N}_{4} \mathrm{O}_{4} \mathrm{~S}_{2}$

324.33

323.998698

Fig. 6 
A

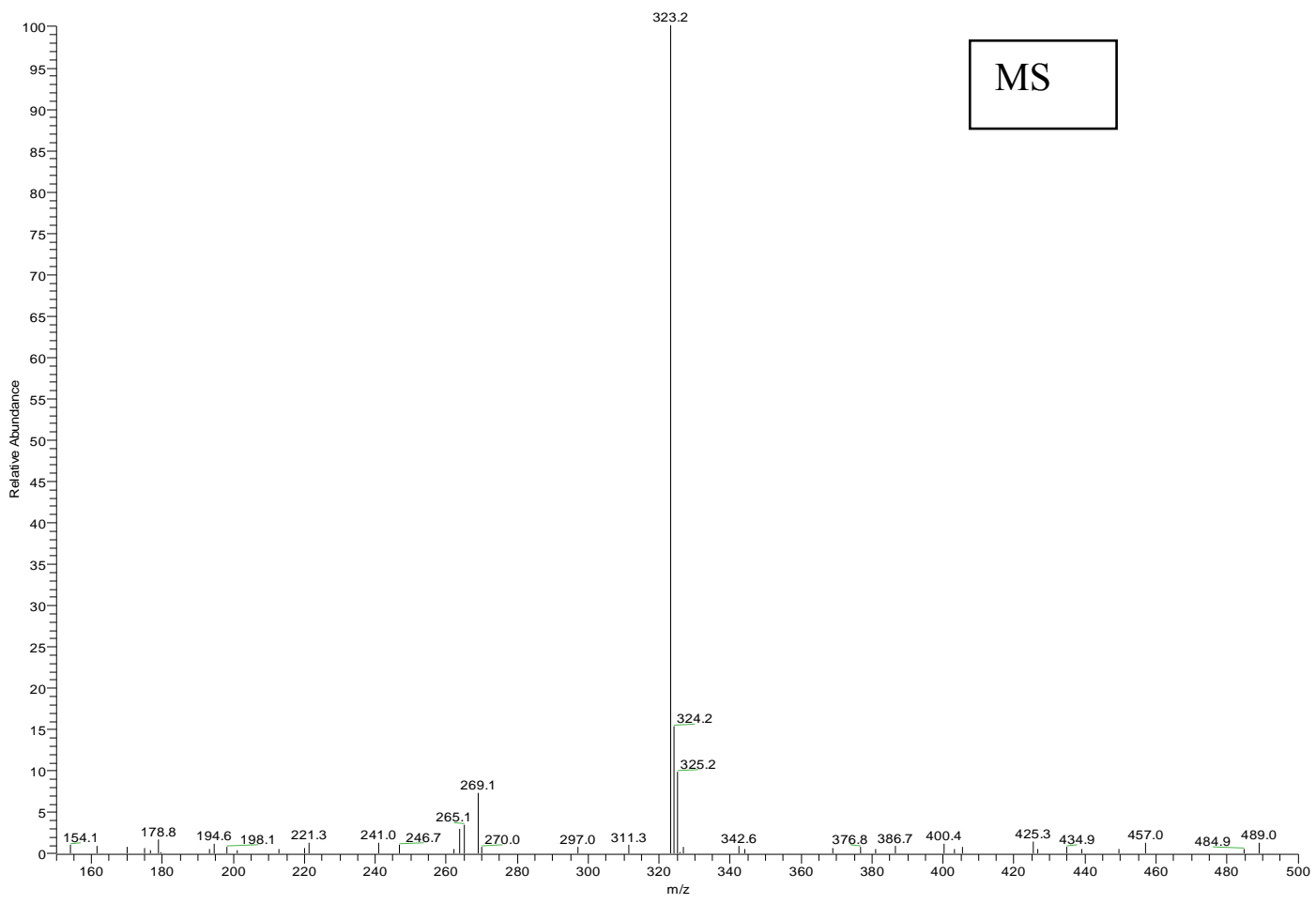

B

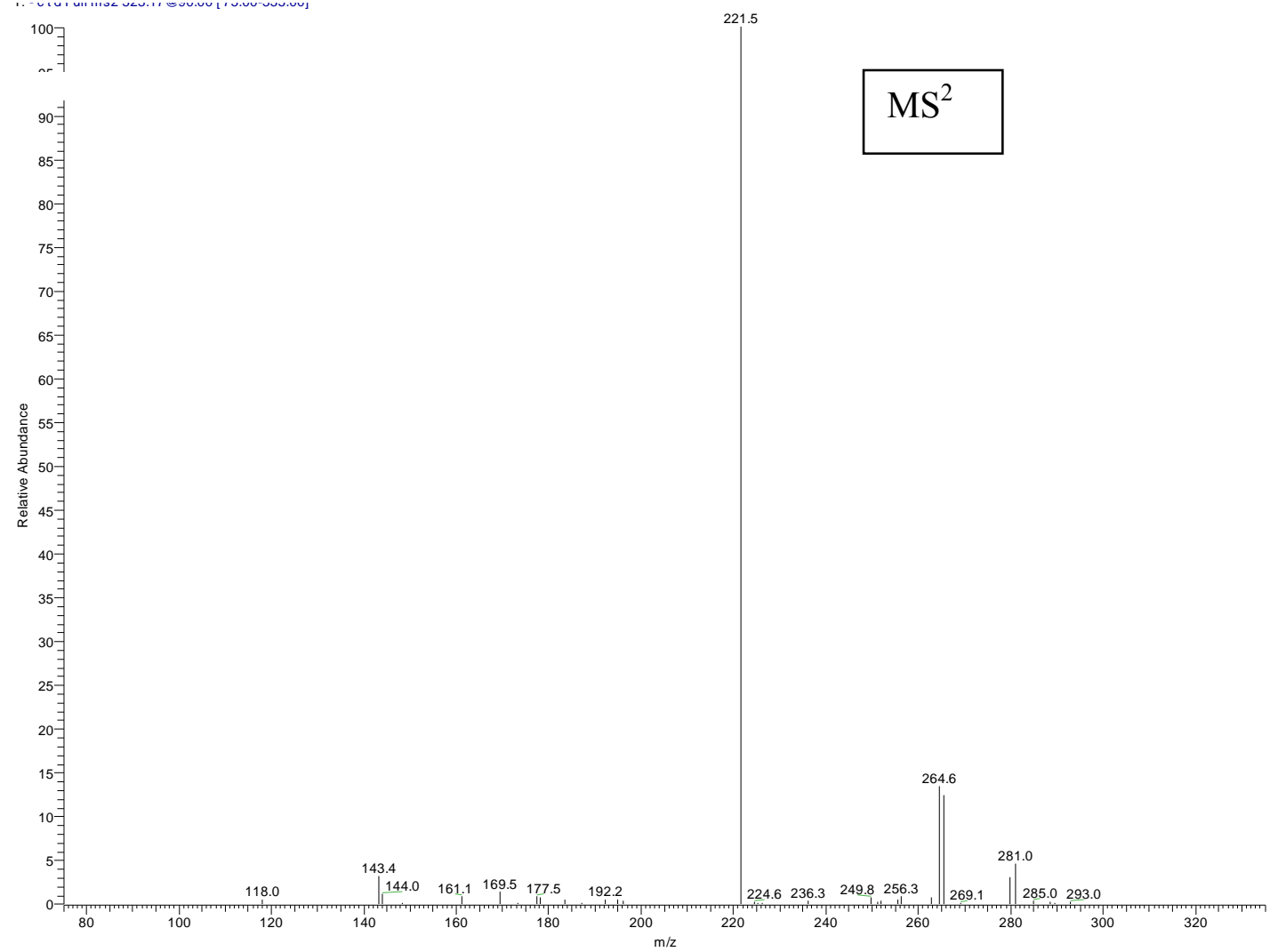




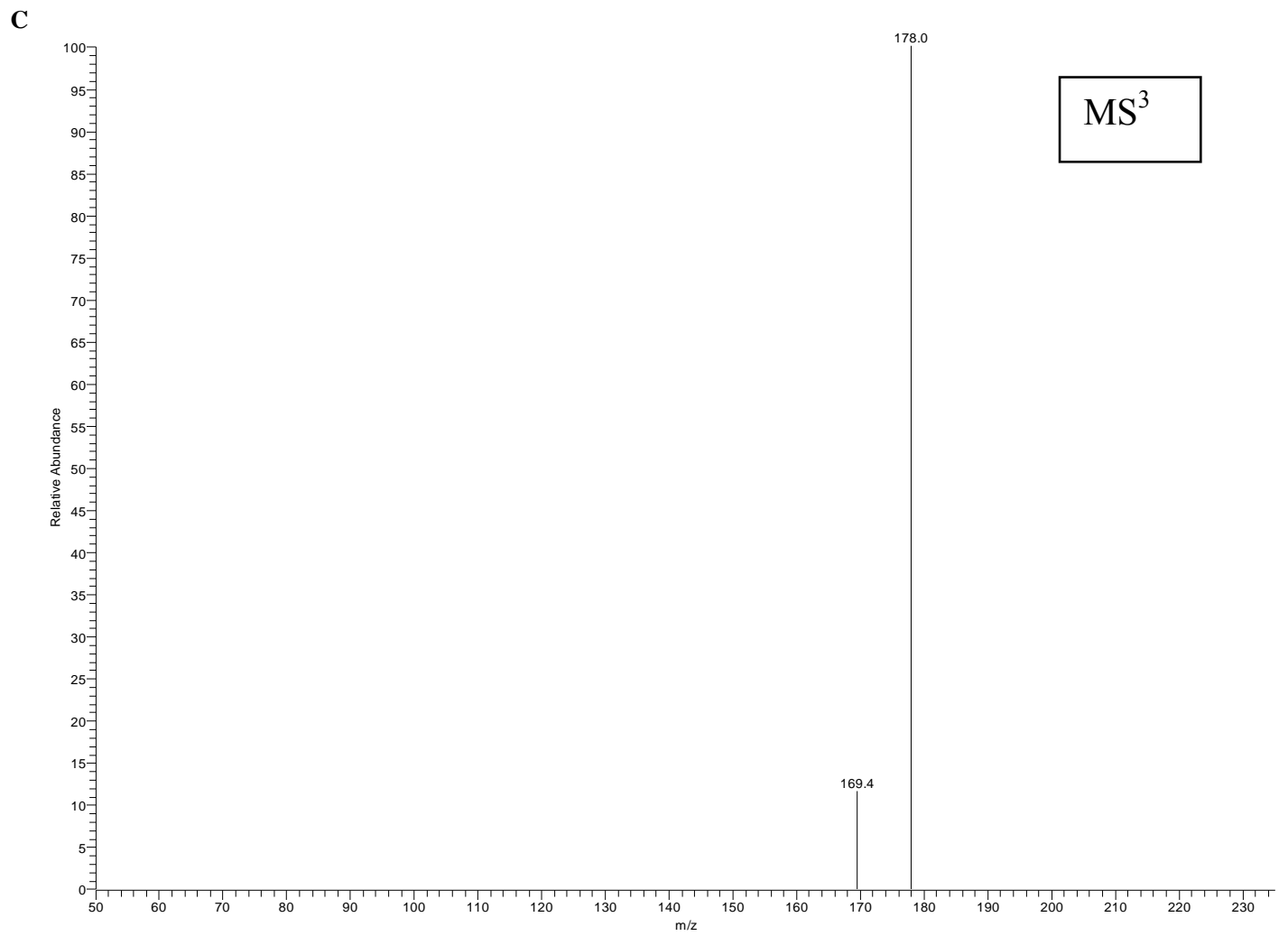

Fig. 7 

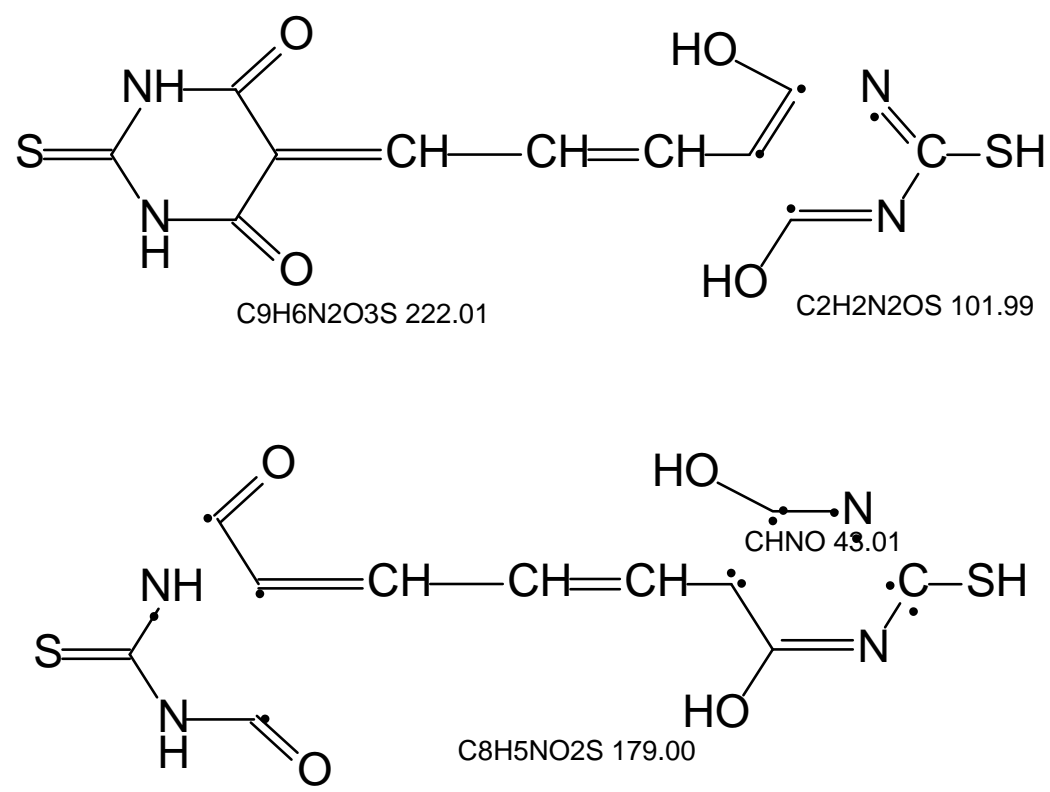

C2H2N2OS 101.99

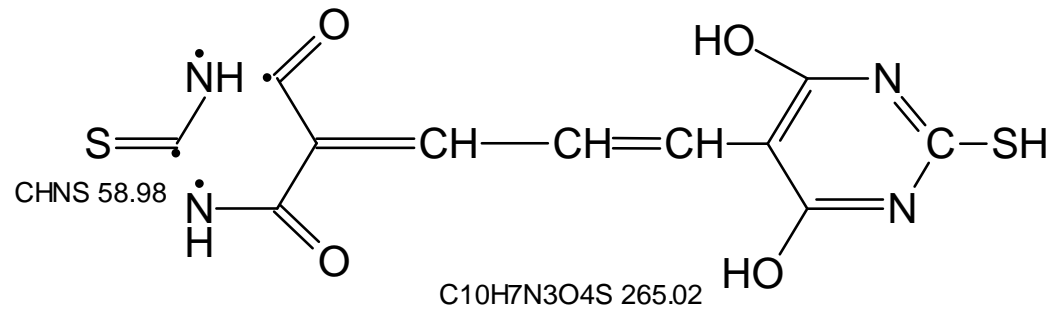

Fig. 8 


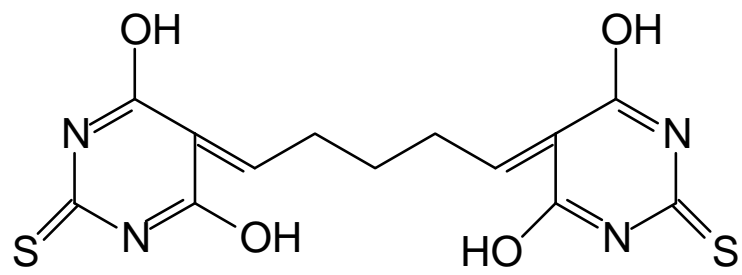

$\mathrm{C}_{13} \mathrm{H}_{12} \mathrm{~N}_{4} \mathrm{O}_{4} \mathrm{~S}_{2}$

352.38

Fig. 9 
<smiles>OC1=NC(=S)N=CC1=CCCCC=C1C(O)=NC(=S)N=C1O</smiles>

C13H11N4O3S2 335.03<smiles>OC1=NC(=S)N=C(O)C1=CCCCI</smiles>

C9H9N2OS 193.04

C4H2N2O2S 141.98 HO $17.00 \dot{\mathrm{O}} \mathrm{H}$

Fig. 10 
A

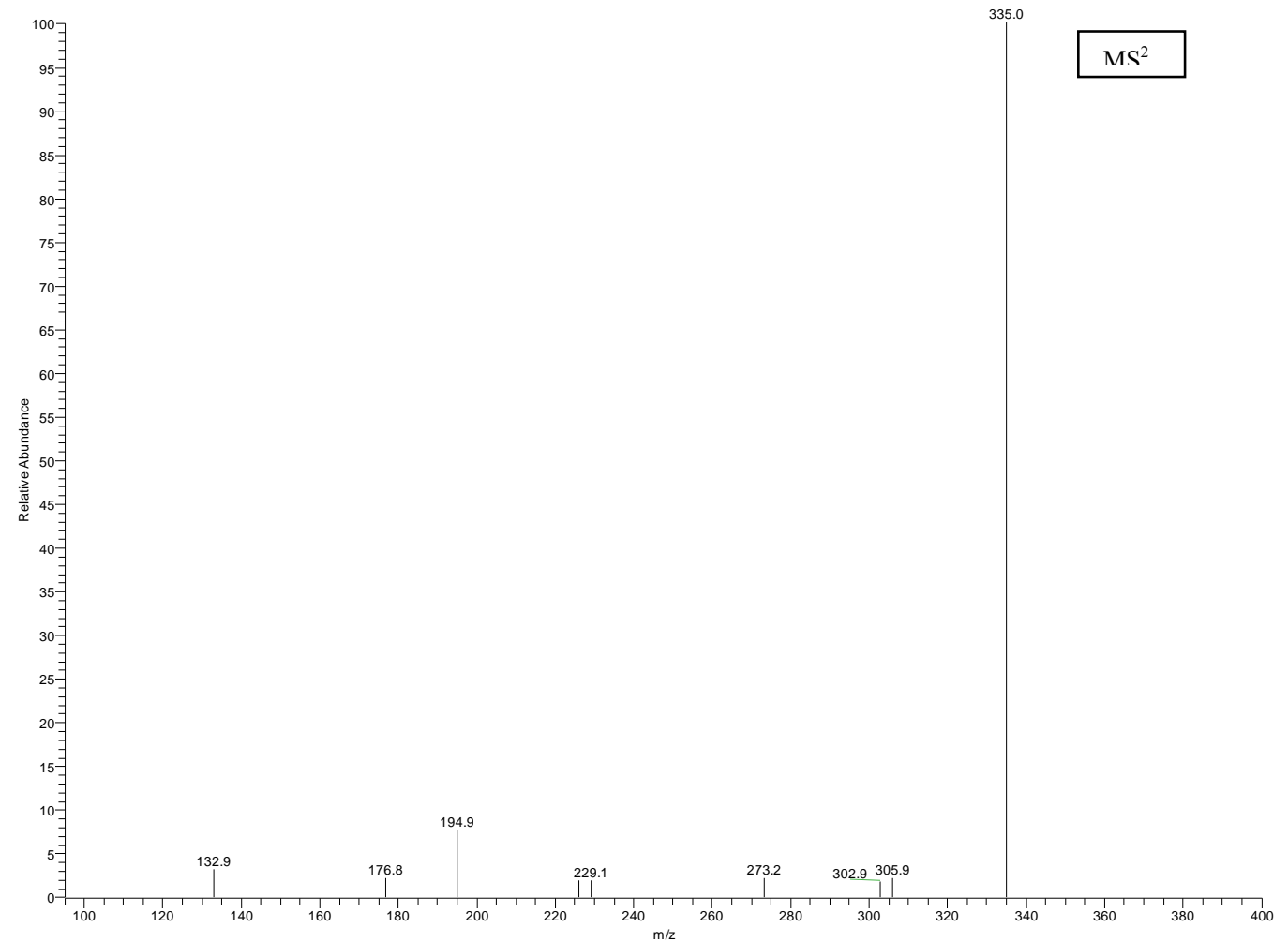

B

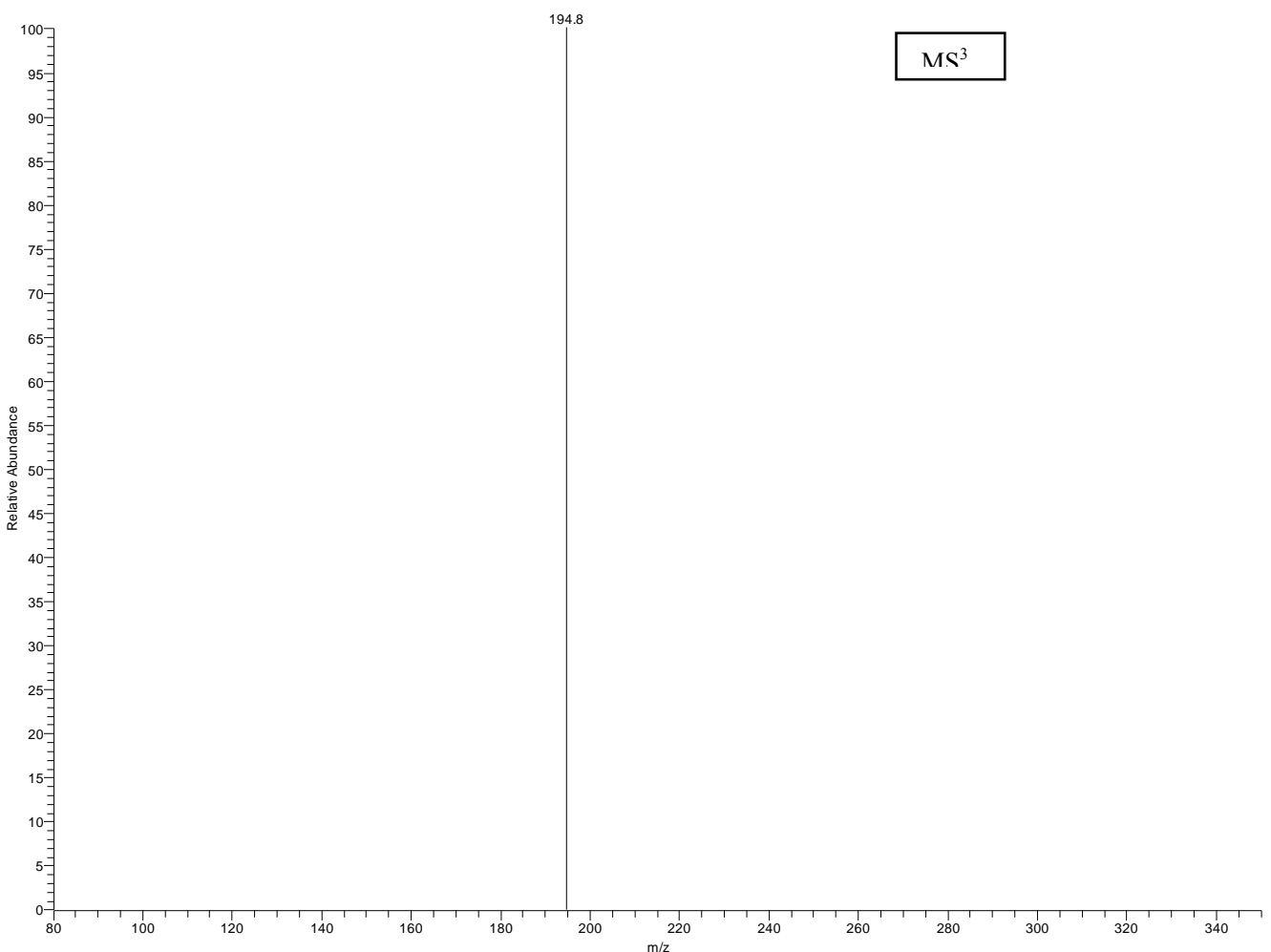

Fig. 11 
<smiles>Oc1cc(O)c2c(c1)OC(c1ccc(O)c(O)c1)C(O)C2</smiles>

(+) - catechin [C]<smiles>O=C(OC1Cc2c(O)cc(O)cc2OC1c1ccc(O)c(O)c1)C1CC(O)=C(O)C(O)C1</smiles>

(-) - catechin gallate [GC]<smiles>Oc1cc(O)c2c(c1)O[C@H](c1cc(O)c(O)c(O)c1)C(O)C2</smiles>

(-) - epigallocatechin [EGC]<smiles>Oc1cc(O)c2c(c1)OC(c1cc(O)c(O)c(O)c1)C(O)C2</smiles>

(+) - gallocatechin [GC]<smiles>Oc1cc(O)c2c(c1)OC(c1ccc(O)c(O)c1)C(O)C2</smiles>

$(-)$ - epicatechin [EC]<smiles>O=C(O[C@H]1Cc2c(O)cc(O)cc2O[C@@H]1c1ccc(O)c(O)c1)c1cc(O)c(O)c(O)c1</smiles>

(-) - epicatechin gallate [ECG]<smiles>O=C(O[C@H]1Cc2c(O)cc(O)cc2O[C@H]1c1cc(O)c(O)c(O)c1)c1cc(O)c(O)c(O)c1</smiles>

(-) - epigallocatechin gallate [EGCG]<smiles>O=C(O[C@H]1Cc2c(O)cc(O)cc2OC1c1cc(O)c(O)c(O)c1)C1CC(O)=C(O)C(O)C1</smiles>

(-) - gallocatechin gallate [GCG]

Fig. 12 
